\title{
Specificity of Sustainable Structural Dynamics of Local Economy in Romanian Tourist Resorts
}

\author{
Alexandra Grecu 1,2®), Andreea Karina Gruia 1,2®, Marian Marin 1,2®), Mariana Bănuță ${ }^{3}$, \\ Cosmin Olteanu ${ }^{4}$, Ionuț Constantin ${ }^{4}$, Mihaela Gadoiu ${ }^{3}$, Camelia Teodorescu 1,2, \\ Răzvan Cătălin Dobrea ${ }^{5}$ and Cristian Constantin Drăghici ${ }^{1,2, *}$ \\ 1 Research Center for Integrated Analysis and Territorial Management, Faculty of Geography, \\ University of Bucharest, 030018 Bucharest, Romania; alexandra.grecu@drd.unibuc.ro (A.G.); \\ andreea.karina.gruia@drd.unibuc.ro (A.K.G.); marian.marin@geo.unibuc.ro (M.M.); \\ camiteo@yahoo.com (C.T.) \\ 2 Faculty of Geography, University of Bucharest, 010041 Bucharest, Romania \\ 3 Faculty of Economic Sciences and Law, University of Pitești, 110014 Pitesti, Romania; \\ mari.banuta@yahoo.com (M.B.); mihaela_gadoiu@yahoo.com (M.G.) \\ 4 Faculty of Administration and Business, University of Bucharest, 4-12, 030018 Bucharest, Romania; \\ olteanu.cosmin@faa.unibuc.ro (C.O.); ionut.constantin@faa.unibuc.ro (I.C.) \\ 5 Faculty of Management, Bucharest University of Economic Studies, 010374 Bucharest, Romania; \\ razvan.dobrea@man.ase.ro \\ * Correspondence: cristian.draghici@geo.unibuc.ro; Tel.: +40-721-818-331
}

Received: 12 November 2019; Accepted: 4 December 2019; Published: 13 December 2019

\begin{abstract}
The lack of sustainable development strategies of the tourist resorts from Romania caused the structural dynamics of their economy to record large fluctuations under the impact of determinants with unpredictable developments. The spectacular dynamics have led to developments difficult to predict, in many situations that generate environmental conflicts, where the economic pressure has exceeded the support capacity of the natural environment. In this study, we aim to analyze the dynamic relationship between tourism and the other components of the economy, from each resort from Romania. The significant growth of tourism in recent years requires new approaches, relevant for understanding the role of tourism in increasing the complexity of the local economy. Measuring the role of tourism in the development of local economy was achieved by building an economic database for all tourist resorts from Romania (according to Government Decision No. 107 of 2018), at the four-digit NACE code level (Classification of National Economy Activities), for the economic indicators considered relevant: number of companies, number of employees, and turnover and profit, for the period 2000-2016, as well as at territorial administrative unit level. Detailed analyses revealed very different structural dynamics, the spectacular dynamics, lacking a coherent strategic framework, led in all situations to the emergence of environmental conflicts. Tourist resorts in which tourism has become an essential component of economic development have based their development on capitalization of local resources, which led to multiplication effects, materialized in a spectacular evolution of the local economy, and an increasing pressure on the natural environment.
\end{abstract}

Keywords: sustainable development; tourist resorts; local economy; territorial management; Romania

\section{Introduction}

Analyzing the global economic development of the last decade, it can be noticed that tourism has become an important sector for local, national, and international economic activities [1], and, with its development, there has been a diversification of both tourist products and destinations [2]. Potential economic benefits of tourism, at national or regional level, is a very discussed topic in the literature 
where the development of the tourism sector leads to possible direct or indirect positive effects on the economy and on the well-being of communities [3-10]. Tourism, is one of the greatest wealth generators, classified as one of the major economic development factors [11], and is often described as a driver of growth and economic development [12], being approached as a priority sector for the Romanian economy, given the potential contribution of general economic recovery.

Tourism is, at the same time, an economic sector that consumes resources and puts pressure on ecosystems. The development of tourism often requires a strong intervention, in a short time, on the environment, generating a whole chain of negative multiplier effects. The analysis of the dynamic relationship between tourism and the other components of the economic system is a good premise for identifying potential imbalances in the natural environment.

As a result, the debate on the sustainability of tourism has become particularly important lately [13-17]. This fact is due, among other things, to the decision-makers who have become increasingly aware of the limitations of using natural and cultural resources, but also the negative impact that tourism, without adequate measures, can have on the environment, on society, and on people [18].

On the other hand, sustainability was considered a key element in the primary models in the specialty literature on tourism competitiveness [19], and some authors have referred, in particular, to environmental sustainability as a key variable for the competitiveness of long-term tourism destinations or for improving the quality of life of the local population [20]. International or intergovernmental organizations as well as the United Nations Environmental Program and World Tourism Organization, have promoted the concept of sustainable tourism as a "balance" appropriate between economic viability, environmental responsibility, and socio-cultural prosperity [21,22].

The analysis of the dynamic relationship between tourism and the other systemic components is a good premise for identifying potential imbalances in the natural environment. In addition, in order to measure and monitor the sustainability of tourism, researchers have developed different techniques, such as the Sustainable Tourism Index, the Global Sustainable Tourism Council Criteria, the Systematic Indicators System, or the Importance-Performance Analysis [23-25].

The role played by the tourism sector in the development of local economies is a critical issue for geographers [26,27], representing one of the most studied topics in tourism studies. Its role in the development of local economies is important due to the complex economic influences that occur both vertically and horizontally in the local economic system [28-32]. Studying this role, held by tourism in the development of local economies, becomes very important for the design and implementation of sustainable management strategies in the medium and long term. Through a management policy on improving services, along with an appropriate marketing policy, tourism can bring significant economic benefits to these communities [33,34]. Thus, the development of methodologies for modeling the relations patterns with the other components of the territorial system is an important goal for both researchers and decision-makers.

The study aims to develop a methodology for analyzing the role of tourism in the development of local economy, based on relevant indicators of economic complexity for each administrative-territorial unit analyzed from Romania for a statistically relevant period of time. Modeling the complex relationship between tourism and the other components of the local economy (agriculture, industry, trade, etc.), will bring new elements of knowledge regarding one of the most dynamic relationships between the components of a territorial system, and designing in this way, the premises that can generate imbalances in the natural environment.

\section{Materials and Methods}

\subsection{Study Area}

In this study, all tourist resorts from Romania are analyzed from the point of view of tourism's contribution to the development of the local economy. The Law of Tourism defines the tourist resort as 
"the locality or part of a locality, which has a tourist heritage and a tourist infrastructure, in which the economic activities mainly support the achievement of the tourism product and which is attested by Government decision, at the proposal of the authority of the central public administration responsible for tourism, in the situation of cumulative fulfillment of the mandatory minimum certification criteria, approved by Government decision". According to the Government Decision no. 107 of 2018, approving the attestation of some localities or parts of localities as tourist resorts of national or local interest and on the change of annex no. 5 to the Government Decision no. 852 of 2008, to approve the rules and the attestation criteria of tourist resorts, in Romania are 108 resorts (47 national interest and 61 local interest). To mention that, although Romania has 108 tourist resorts, in cartographic representation there are only 98, since: Băile Felix and 1 Mai; Crivaia and Semenic; North Eforie and South Eforie; Mangalia, Cap Aurora, Jupiter, Neptun-Olimp, Saturn and Venus; Predeal, Pârâul Rece and Timișul de Sus, share the same territorial administrative unit. The cartographic model was developed with the help of open-source software QGis (Grüt, Switzerland), which represents the spatial distribution of tourist resorts at both, national and regional level (Figure 1).

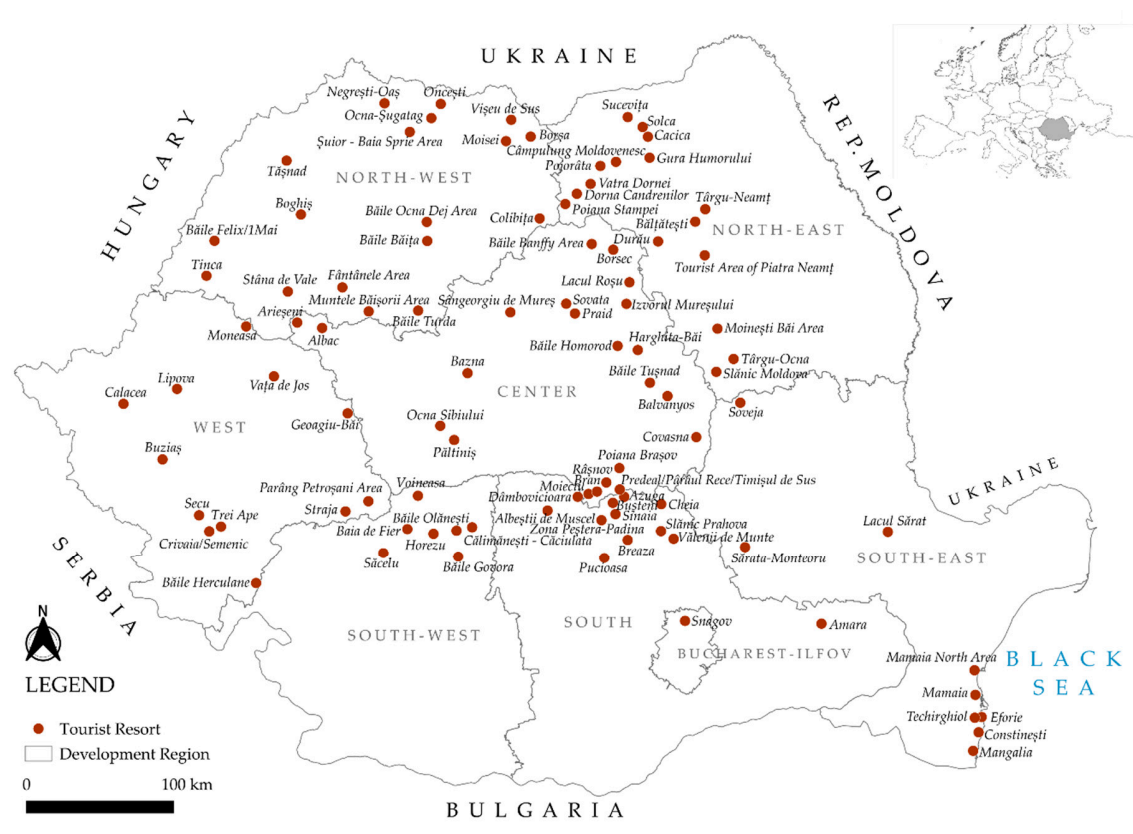

Figure 1. The distribution of tourist resorts in Romania.

\subsection{Data Analysis}

The study is based on the development of an economic database, both at the territorial administrative unit level, and four-digit NACE code (Classification of National Economy Activities) with the four economic indicators relevant to tourism development in each resort in Romania, for the period 2000-2016 (number of companies, number of employees, turnover, and profit). Based on this, were made evolution charts for the aforementioned indicators, for analyzing the share of tourism in the total local economy for the tourist resorts, as well as for the evolution of the three sectors of activity (primary, secondary, and tertiary), highlighting the tourism sector, for the same period. The database for the turnover and profit was represented in Romanian currency, Ron, where 1 Ron is equal to $0.28 €$ (Euro), average course calculated for the period 2000-2016. To identify the structural dynamics of tourist resorts, an analysis of the variation of the ranks held by each resort was made by: the share of the company's number from tourism sector in total number of companies, the share of the employee's number from tourism sector in total number of employees, the share of turnover from tourism sector in total turnover, and the share of the profit from tourism sector in total profit. In the end, we made a matrix with the variation of ranks with the arithmetic mean of the share of the four economic indicators from tourism sector for each resort. For the matrix, each resort has been given a certain color: red for 
resorts that showed a declining trend, orange for a relatively constant evolution, i.e., their evolution does not show large fluctuations, and green for those resorts that experienced an increase in rank over the period under review. The analysis of the relationship between the increase of the role of tourism in the local economy and the environmental conflicts was done by creating a database on their number, recorded in official documents. Thus, by associating their number with the evolution trend of this relationship, the direct link between tourism developments has been observed, in most cases in a short period, and also the generation of environmental conflicts.

\section{Results}

In the territorial systems with touristic functionality from Romania, the total number of companies is showing an upward dynamics from the first year of the analysis, 2000, until 2008, with an increase of about $69 \%$, the tourism sector contributing to this evolution with values between $3 \%$ and $3.4 \%$ (Figure 2). While the total number of companies declined after 2008, with about $7 \%$ due to the global economic crisis, those from the tourism sector have registered an upward trend, from 2668 companies in 2008 , to 2742 in the last year of analysis, this growth amounting to $2.7 \%$. The main areas of tourism where the number of companies increased were: hotels and other similar accommodation facilities, tourist agency activities, and tour operator activities, and the main resorts where these rises were produced were Mamaia, Eforie, Păltiniş.

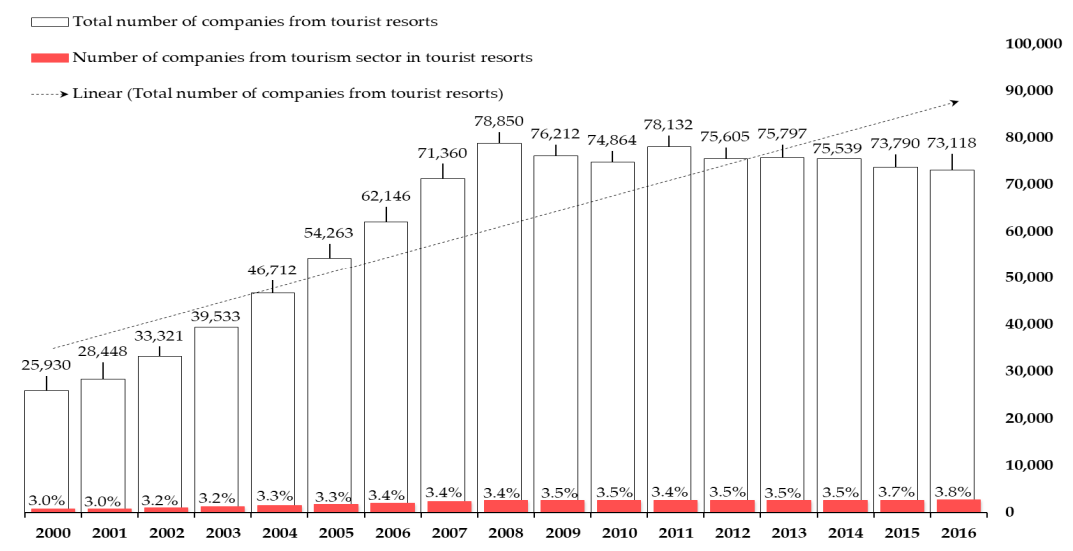

Figure 2. Total number of companies from total economy and from tourism sector in tourist resorts from Romania.

Regarding the number of employees (Figure 3), things are similar to the number of companies, but with few exceptions. Here, the economic crisis has been felt since 2007, with a sharp decline of around $24 \%$ by 2010 . After this period, the number of active employees in tourist resorts enters a trajectory with small fluctuations. As for the tourism sector, the number of employees is variable throughout the analyzed period, their percentage oscillating from year to year, with the highest value being in 2016, when out of a total of 410,223 employees, 18,371 were active in tourism. As the main areas of tourism activity are: hotels and other similar accommodation facilities, accommodation facilities for holidays and short-term periods, other accommodation services, other reservation and tourist assistance services, and tourism agency activities.

Both the turnover and the profit of tourist resorts (Figures 4 and 5) follow the same well-known growth path until 2008, then they decrease over the next period, that is attributed to the economic crisis and which has made its mark especially in the case of profit, its decrease from 2008 to 2009 being about $24 \%$, and a spectacular recovery for both indicators over the past two years of the analysis that can be attributed to new investments. Additionally, in the last two years of the analysis, 2015 and 2016, there are changes in the share of the tourism sector, so it decreases in the case of turnover and increases for profit. 


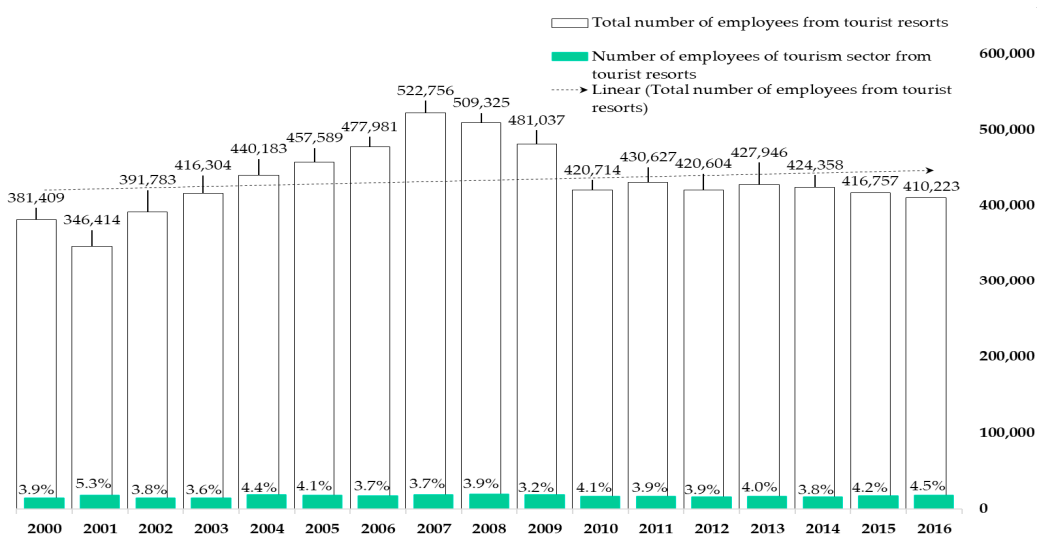

Figure 3. The number of employees from total economy and from tourism sector in tourist resorts from Romania.

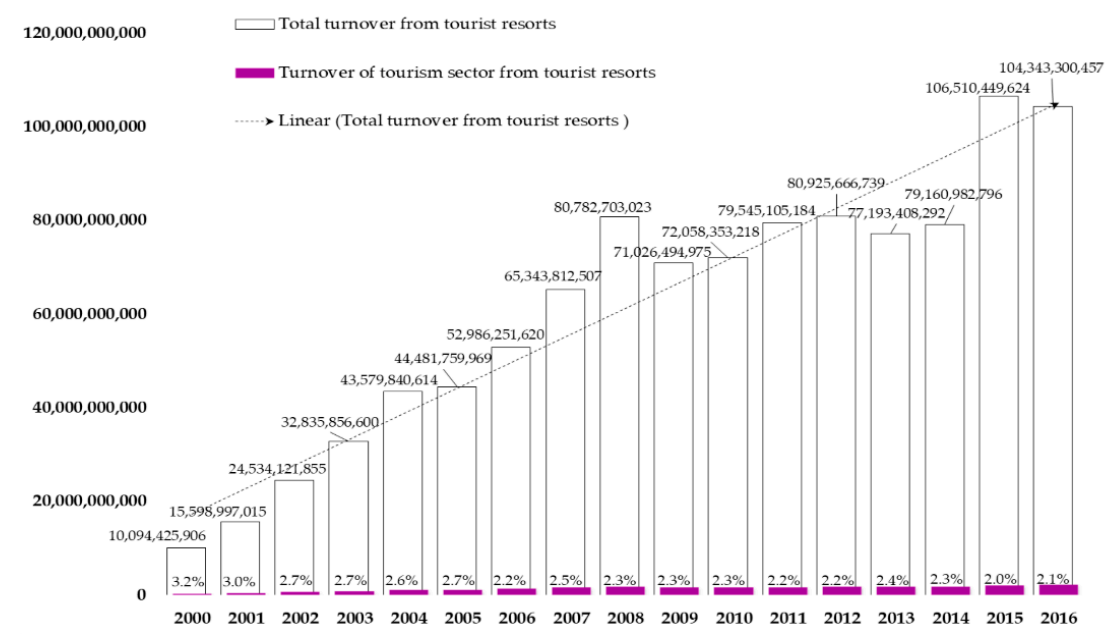

Figure 4. Total turnover from total economy and from tourism sector in tourist resorts from Romania (values represented in Ron, where 1 Ron $=0.28 €$, average course calculated for the period 2000-2016).

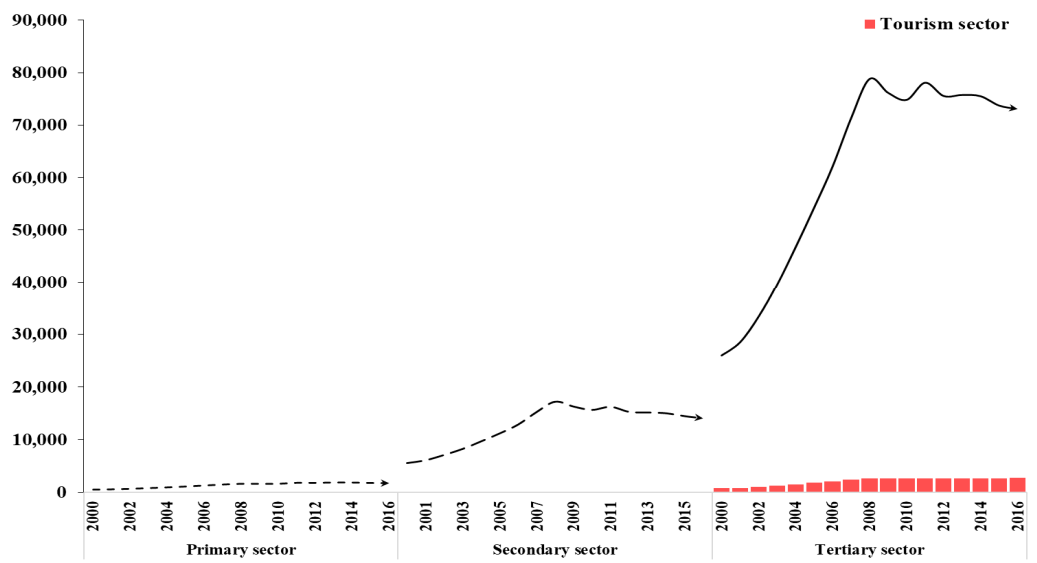

Figure 5. Evolution of the number of companies by sectors of activity and the evolution of the tourism sector in the tertiary sector in tourist resorts.

Figure 4 Total turnover from total economy and from tourism sector in tourist resorts from Romania (values represented in Ron, where 1 Ron $=0.28 €$, average course calculated for the period 2000-2016). 
For the number of companies, the tertiary sector, which includes services, water distribution, and electricity production, holds the largest share of the companies at the level of the resorts: $76.8 \%$ in 2000, 76.2\% in 2008, and 78.5\% in 2016 (Figure 5). Tourism, which is part of this sector, makes an economic contribution between $3 \%$ and $3.7 \%$. Its contribution throughout the period analyzed is increasing. Of the total number of companies that existed in 2016 in the tertiary sector, 73,118, 2727 were active in tourism. The second sector, which records a significant number of firms, is the secondary one with main areas of activity: manufacture of other outerwear, sawmilling and planning of wood, manufacture of communication equipment, construction of residential and non-residential buildings, plumbing, heat, and air-conditioning installation. On the last place is the primary sector, which brings the lowest economic contribution to resorts, not exceeding the threshold of 2000 firms, accounting for $2.5 \%$ of the total local economy. It should be mentioned that during the whole period analyzed, the number of companies in the tourism sector exceeds the number of companies in the primary sector.

Regarding the number of employees (Figure 6), in the first years of analysis, the sector in which most employees were employed was the secondary one. After 2004, the main sector of activity with the largest number of employees becomes the tertiary sector, with about $59 \%$ of the total number. Tourism contributes between $6.8 \%$ and $10.8 \%$ in terms of the number of employees in the tertiary sector. Of the total number of employees in this sector in $2016(242,973), 18,371$ were active in the tourism sector. As for the primary sector, it has the lowest number, its share declining year to year, so in 2016 records show only 9833 employees, mostly in the field of growing of cereals (except rice), leguminous crops, and oil seeds. Starting with 2013, the number of tourism employees exceeded the number of those active in the primary sector.

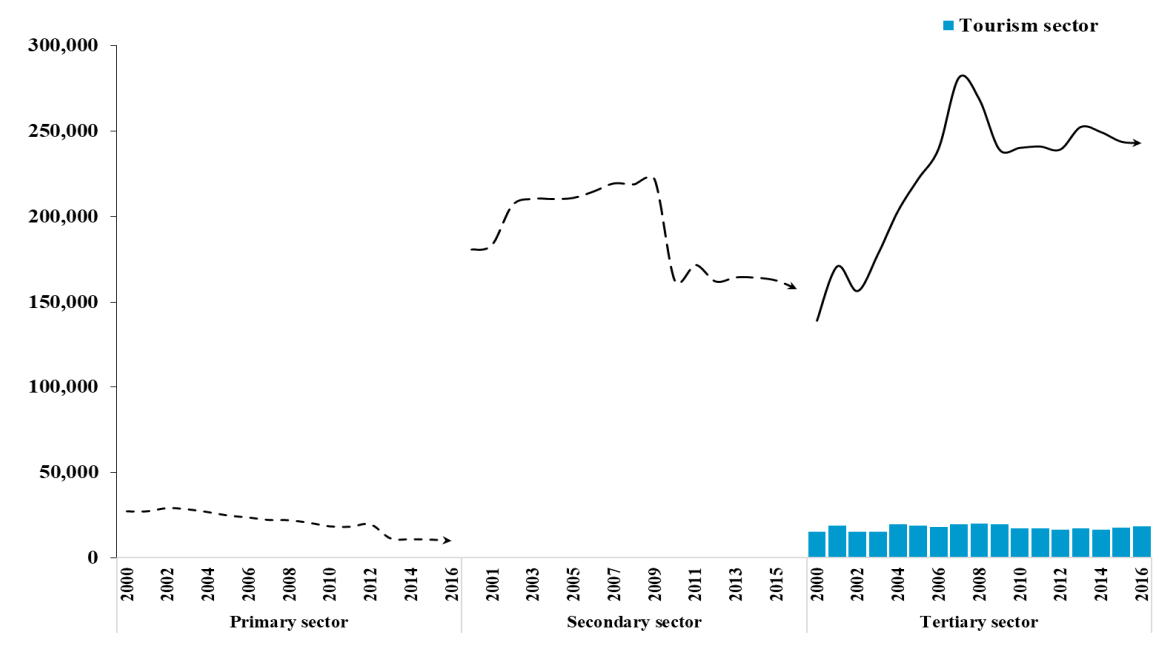

Figure 6. Evolution of the number of employees by sectors of activity and the evolution of the tourism sector in the tertiary sector in tourist resorts.

Turnover (Figure 7) and profit (Figure 8), present the same ascending trend pattern, with fluctuations, with increases up to 2008 and with a recovery in the next period. The tertiary sector is the one with the highest turnover and profit from tourist resorts with a share of $57 \%$ and $63.9 \%$ for 2016 , followed by the secondary sector, with a lower economic contribution, but significant, of $40 \%$ and $31.5 \%$. The contribution of tourism to the two indicators, the turnover and profit, in the tertiary sector is between $3.6 \%$ and $6.1 \%$, respectively $3.9 \%$ and $13.6 \%$. The sector with the smallest share of the economy of these systems is the primary one, where in any year of the analysis period, does not exceed the value threshold of 4,039,940.47 Ron $(847,539.11 €$, where 1 Ron $=0.28 €)$ for the turnover, respectively $499,851,582$ Ron for profit $(104,863,863.39 €)$. 


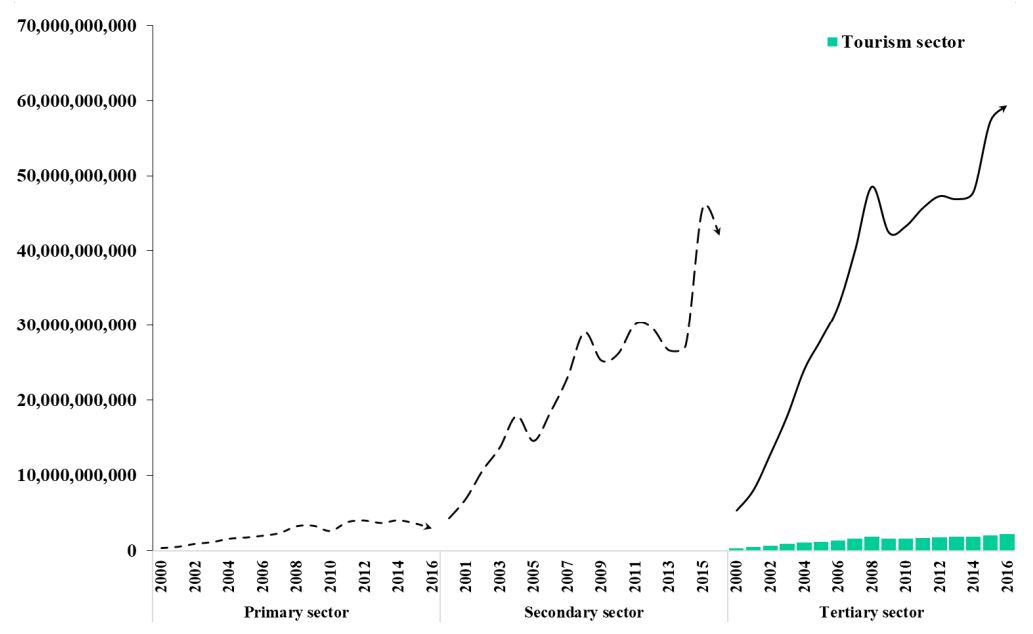

Figure 7. Evolution of turnover by sectors of activity and the evolution of the tourism sector in the tertiary sector in tourist resorts (values represented in Ron, where 1 Ron $=0.28 €$, average course calculated for the period 2000-2016).

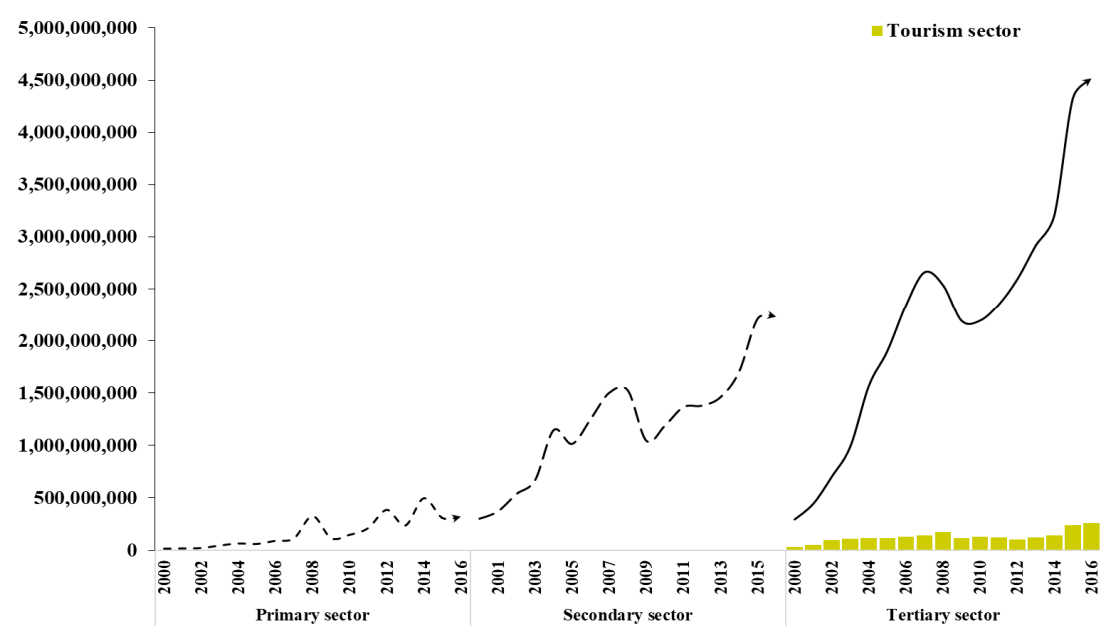

Figure 8. Evolution of profit by sectors of activity and the evolution of the tourism sector in the tertiary sector in tourist resorts (values represented in Ron, where 1 Ron $=0.28 €$, average course calculated for the period 2000-2016).

Analysis of the rankings held by the share of the tourism sector in the total number of companies in tourist resorts from Romania (Table 1), shows a predominance of those who, over the 17 years, have a relatively constant trend with a share of $53.1 \%$ of the total number of resorts. These resorts did not show large fluctuations in the occupied rank and they have maintained their position throughout the period (Azuga, Covasna, Sinaia, Bran, Breaza, etc.). The second category is occupied by the ones with a general trend of decrease, where tourism is not their main activity, and natural resources can not support their development. They stand out with a fairly high share of about 29.6\% (Amara, Mangalia, Eforie, Geoagiu-Băi, Techirghiol, Stâna de Vale, Lacul Sărat, Săcelu, etc.). The last category identified is that of the resorts with a general trend of growth where tourism has led to local economic development: Băile Herculane, Dâmbovicioara, Slănic Moldova, Arieșeni, Crivaia/Semenic, Moieciu, Ocna Șugatag, etc. The share held by these resorts is only $17.3 \%$. 
Table 1. Variation of the rankings for the share of number of companies from the tourism sector in the total number of companies.

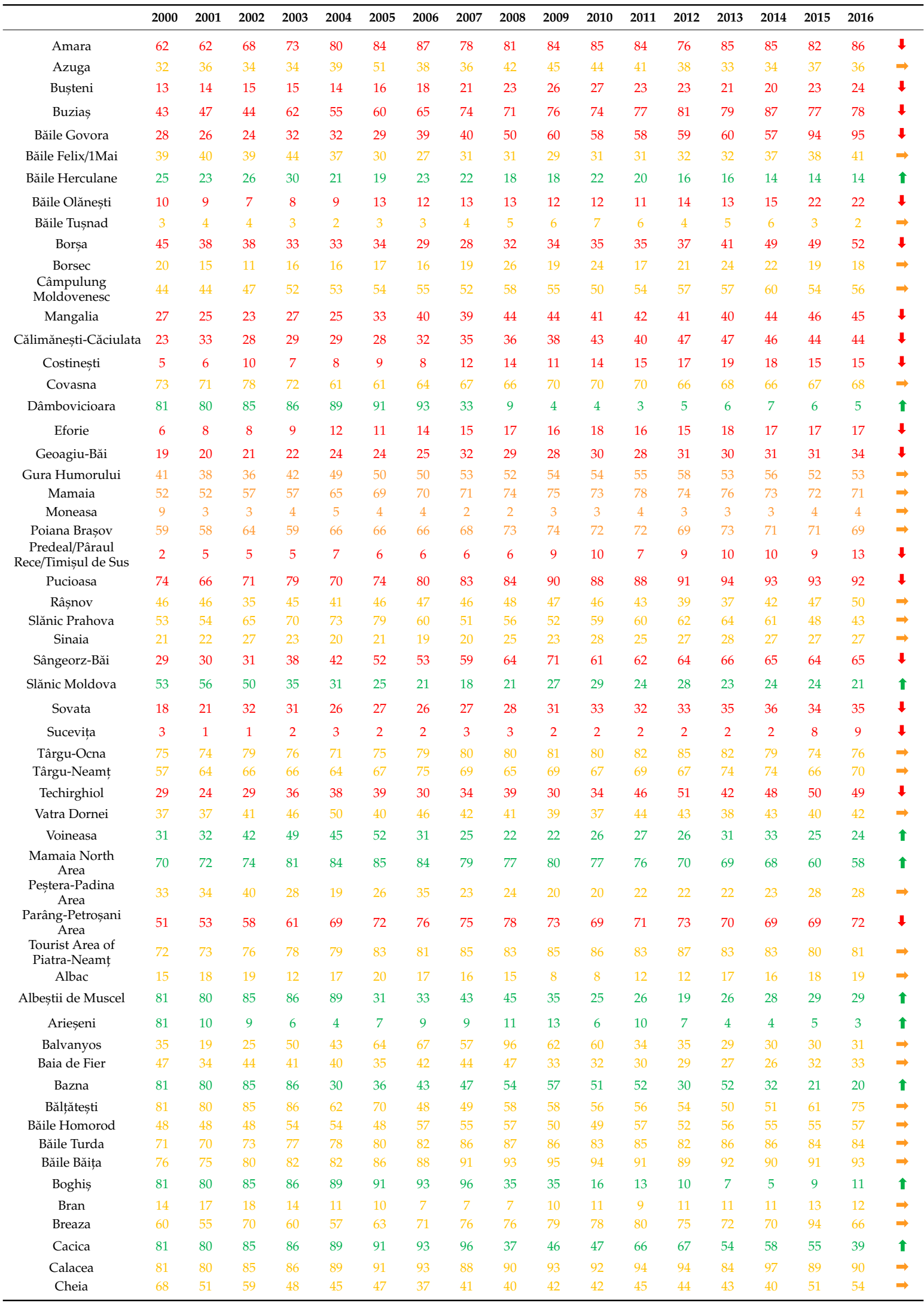


Table 1. Cont.

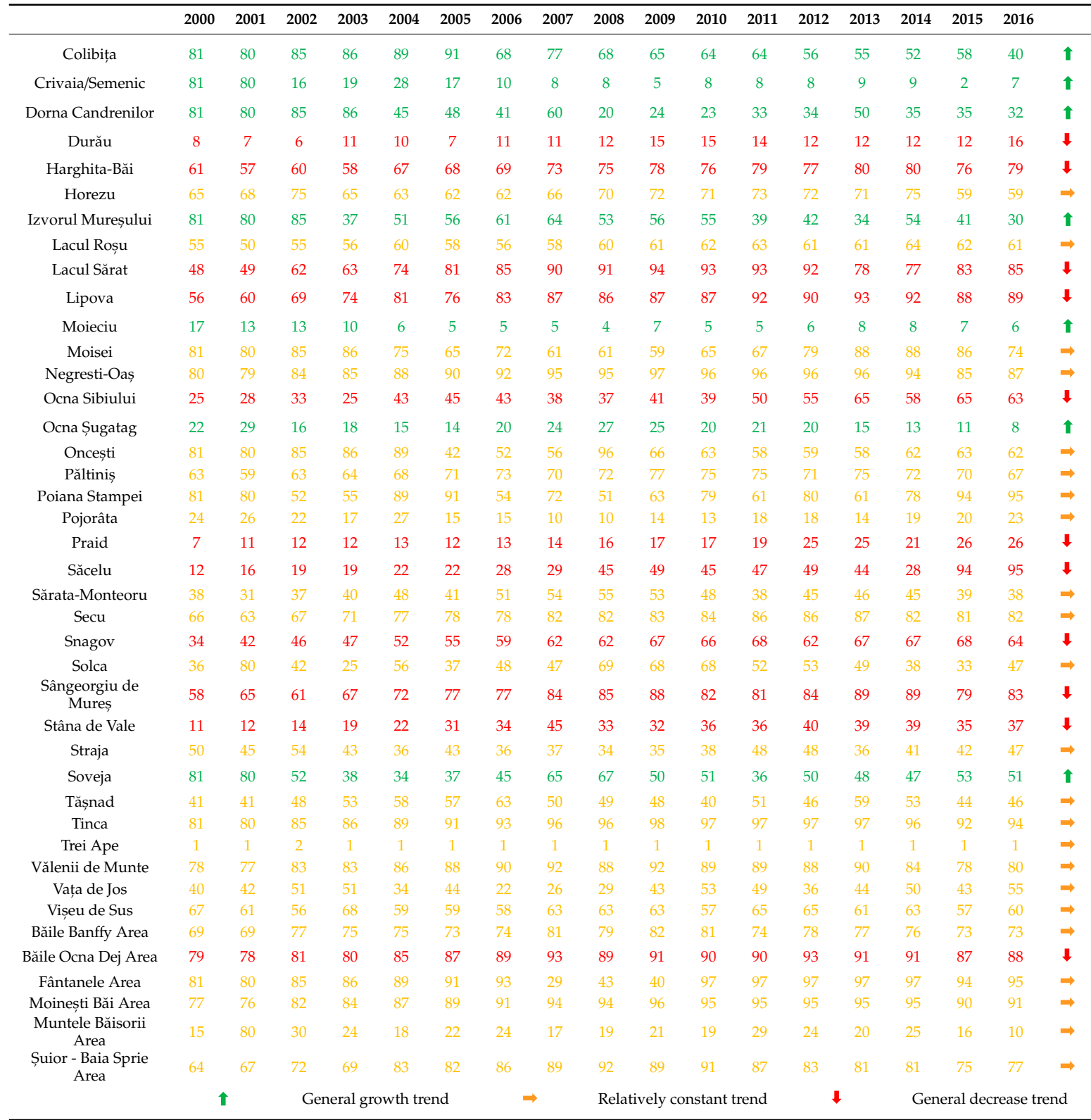

Analyzing the variation of the ranks held by the share of tourism in the number of employees, we have the following situation (Table 2): 31 resorts, i.e., 31.6\%, have a general decline trend, 17 resorts, 17.4 \% registered an increasing number of employees in the tourism sector (Călimănești-Căciulata, Bran, Ocna Șugatag, Muntele Băișorii Area, etc.), and the highest number and percentage is held by resorts which during the 17 years had a constant trend (58.1\%). 
Table 2. Variation of the rankings for the share of number of employees from the tourism sector in the total number of employees.

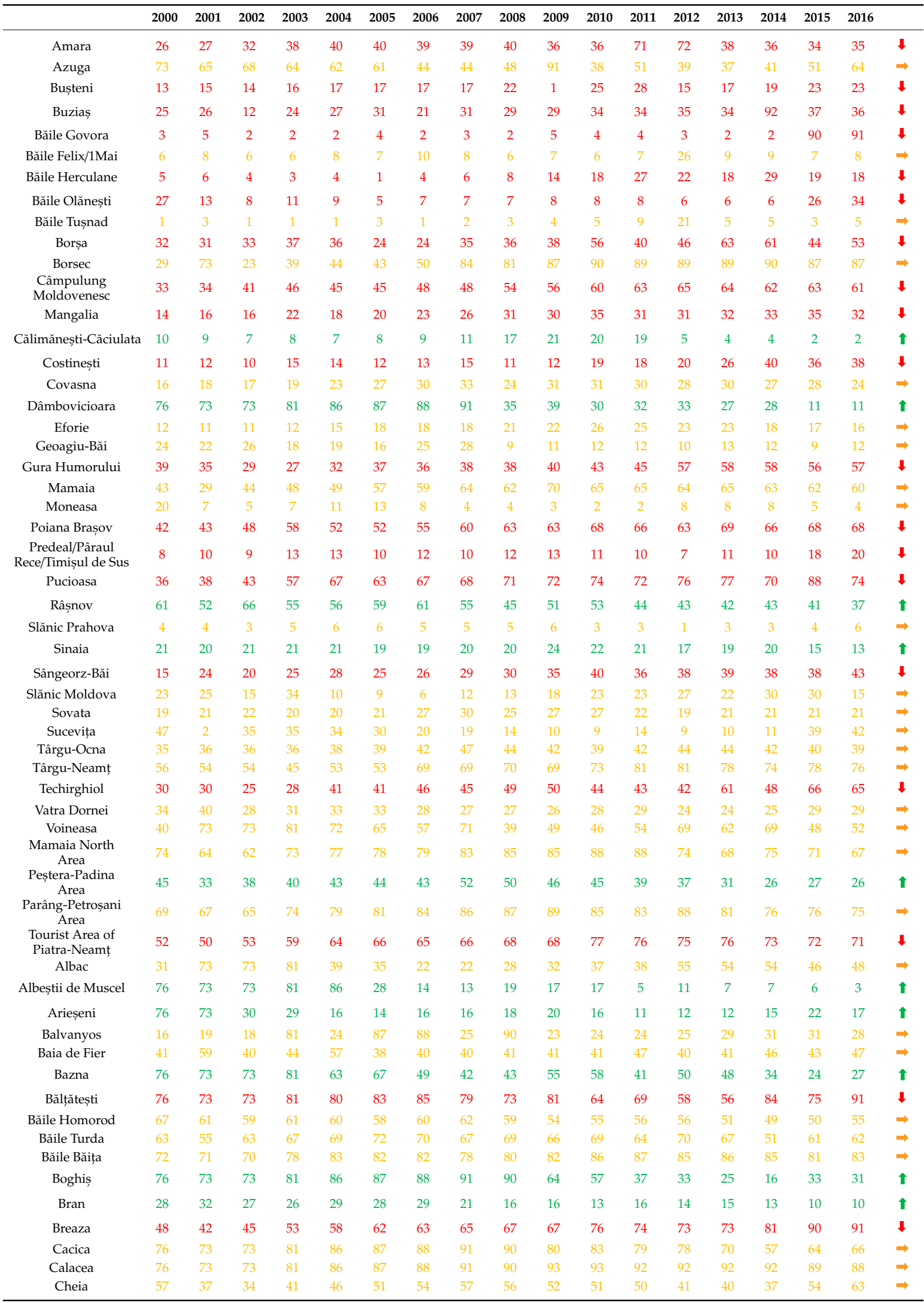


Table 2. Cont.

\begin{tabular}{|c|c|c|c|c|c|c|c|c|c|c|c|c|c|c|c|c|c|c|}
\hline & 2000 & 2001 & 2002 & 2003 & 2004 & 2005 & 2006 & 2007 & 2008 & 2009 & 2010 & 2011 & 2012 & 2013 & 2014 & 2015 & 2016 & \\
\hline Colibița & 76 & 73 & 73 & 81 & 86 & 87 & 88 & 91 & 90 & 78 & 75 & 70 & 61 & 52 & 65 & 65 & 69 & $\Rightarrow$ \\
\hline Crivaia/Semenic & 76 & 73 & 73 & 10 & 5 & 15 & 11 & 9 & 10 & 9 & 7 & 6 & 2 & 14 & 39 & 20 & 33 & $\downarrow$ \\
\hline Durău & 9 & 23 & 24 & 14 & 12 & 11 & 15 & 14 & 15 & 15 & 15 & 13 & 29 & 35 & 35 & 8 & 14 & $\Rightarrow$ \\
\hline Harghita-Băi & 62 & 48 & 57 & 60 & 65 & 64 & 68 & 70 & 72 & 71 & 78 & 77 & 79 & 80 & 71 & 74 & 77 & $\downarrow$ \\
\hline Horezu & 22 & 28 & 31 & 33 & 42 & 46 & 51 & 51 & 55 & 48 & 50 & 49 & 54 & 50 & 56 & 57 & 49 & $\downarrow$ \\
\hline Lacul Roșu & 38 & 62 & 47 & 49 & 59 & 55 & 58 & 58 & 61 & 65 & 62 & 59 & 60 & 66 & 64 & 58 & 54 & $\Rightarrow$ \\
\hline Lacul Sărat & 70 & 69 & 69 & 77 & 78 & 75 & 80 & 75 & 79 & 77 & 80 & 80 & 77 & 82 & 78 & 82 & 80 & $\Rightarrow$ \\
\hline Lipova & 49 & 47 & 50 & 51 & 61 & 54 & 56 & 63 & 65 & 62 & 67 & 68 & 66 & 71 & 68 & 70 & 70 & $\downarrow$ \\
\hline Moieciu & 51 & 41 & 37 & 32 & 30 & 34 & 32 & 24 & 23 & 25 & 21 & 17 & 18 & 20 & 17 & 13 & 22 & $\boldsymbol{\uparrow}$ \\
\hline Moisei & 76 & 73 & 73 & 81 & 86 & 87 & 88 & 88 & 84 & 45 & 47 & 52 & 49 & 88 & 89 & 85 & 90 & $\downarrow$ \\
\hline Păltiniș & 50 & 56 & 46 & 47 & 50 & 50 & 66 & 56 & 57 & 57 & 59 & 57 & 52 & 55 & 55 & 55 & 59 & $\Rightarrow$ \\
\hline Poiana Stampei & 76 & 73 & 73 & 81 & 86 & 87 & 45 & 46 & 42 & 61 & 61 & 73 & 93 & 49 & 83 & 90 & 91 & $\downarrow$ \\
\hline Pojorâta & 66 & 68 & 51 & 52 & 54 & 49 & 47 & 50 & 47 & 43 & 49 & 46 & 48 & 45 & 47 & 47 & 44 & $\mathbf{1}$ \\
\hline Praid & 18 & 17 & 19 & 23 & 22 & 22 & 31 & 23 & 33 & 34 & 33 & 35 & 32 & 33 & 32 & 32 & 30 & $\downarrow$ \\
\hline Săcelu & 76 & 73 & 73 & 9 & 26 & 23 & 41 & 37 & 46 & 93 & 93 & 94 & 93 & 93 & 92 & 90 & 91 & $\downarrow$ \\
\hline Sărata-Monteoru & 55 & 45 & 52 & 30 & 31 & 36 & 35 & 32 & 32 & 33 & 32 & 33 & 36 & 28 & 23 & 25 & 25 & $\mathbf{\uparrow}$ \\
\hline Secu & 54 & 49 & 56 & 68 & 76 & 77 & 78 & 80 & 83 & 84 & 87 & 85 & 84 & 84 & 82 & 77 & 81 & $\downarrow$ \\
\hline Snagov & 46 & 58 & 73 & 81 & 86 & 69 & 72 & 61 & 64 & 58 & 63 & 58 & 62 & 60 & 72 & 45 & 40 & $\Rightarrow$ \\
\hline Solca & 76 & 73 & 73 & 56 & 51 & 56 & 37 & 49 & 60 & 59 & 66 & 62 & 93 & 93 & 14 & 14 & 9 & $\boldsymbol{\uparrow}$ \\
\hline Vălenii de Munte & 71 & 70 & 72 & 80 & 85 & 86 & 87 & 90 & 88 & 92 & 92 & 91 & 87 & 87 & 88 & 83 & 85 & $\Rightarrow$ \\
\hline Vața de Jos & 53 & 53 & 60 & 70 & 74 & 70 & 71 & 74 & 58 & 60 & 70 & 60 & 47 & 53 & 52 & 53 & 84 & $\Rightarrow$ \\
\hline Vișeu de Sus & 60 & 57 & 58 & 62 & 68 & 74 & 76 & 72 & 75 & 73 & 79 & 75 & 67 & 72 & 67 & 60 & 46 & $\Rightarrow$ \\
\hline Băile Banffy Area & 68 & 66 & 67 & 76 & 82 & 84 & 81 & 85 & 86 & 88 & 89 & 90 & 86 & 85 & 87 & 80 & 82 & $\Rightarrow$ \\
\hline Băile Ocna Dej Area & 65 & 63 & 61 & 69 & 71 & 71 & 74 & 76 & 77 & 79 & 81 & 84 & 83 & 83 & 80 & 79 & 79 & $\Rightarrow$ \\
\hline Fântanele Area & 76 & 73 & 73 & 81 & 86 & 87 & 88 & 34 & 90 & 93 & 93 & 94 & 93 & 93 & 92 & 90 & 91 & $\Rightarrow$ \\
\hline Moinești Băi Area & 44 & 46 & 64 & 75 & 81 & 80 & 75 & 73 & 76 & 83 & 82 & 86 & 90 & 91 & 86 & 86 & 89 & $\downarrow$ \\
\hline $\begin{array}{c}\text { Muntele Băisorii } \\
\text { Area }\end{array}$ & 76 & 73 & 73 & 42 & 35 & 26 & 33 & 41 & 37 & 37 & 14 & 20 & 30 & 43 & 22 & 12 & 7 & $\boldsymbol{1}$ \\
\hline \multirow{2}{*}{$\begin{array}{c}\text { Șuior - Baia Sprie } \\
\text { Area }\end{array}$} & 64 & 51 & 42 & 43 & 48 & 47 & 52 & 53 & 52 & 75 & 48 & 53 & 53 & 59 & 60 & 59 & 56 & $\Rightarrow$ \\
\hline & & & $\boldsymbol{1}$ & \multicolumn{4}{|c|}{ General growth trend } & \multicolumn{2}{|c|}{$\Rightarrow$} & \multicolumn{4}{|c|}{ Relatively constant trend } & \multicolumn{2}{|c|}{$\downarrow$} & \multicolumn{3}{|c|}{$\begin{array}{l}\text { General decrease } \\
\text { trend }\end{array}$} \\
\hline
\end{tabular}

Table 3 illustrates the variation of the ranks held by the turnover from tourism sector, which shows a predominance of the resorts that have a relatively constant trend throughout the analyzed period, with a share of $57.1 \%$ of the total number of resorts. The second category is that of the resorts with a general downward trend, with a share of $27.6 \%$. These are resorts where tourism is not a major activity, but a complementary one. As examples of downward trending resorts, we can mention Horezu, Lipova, Săcelul, Câmpulung Moldovenesc, Borsec, and Pucioasa. With a share of only 15.3\%, there are resorts that registered a general growth trend during the period 2000-2016: Dâmbovicioara, Moneasa, Sinaia, Zona Peștera-Padina, Albeștii de Muscel, Crivaia/Semenic etc. 
Table 3. Variation of the rankings for the share of turnover from the tourism sector in the total turnover.

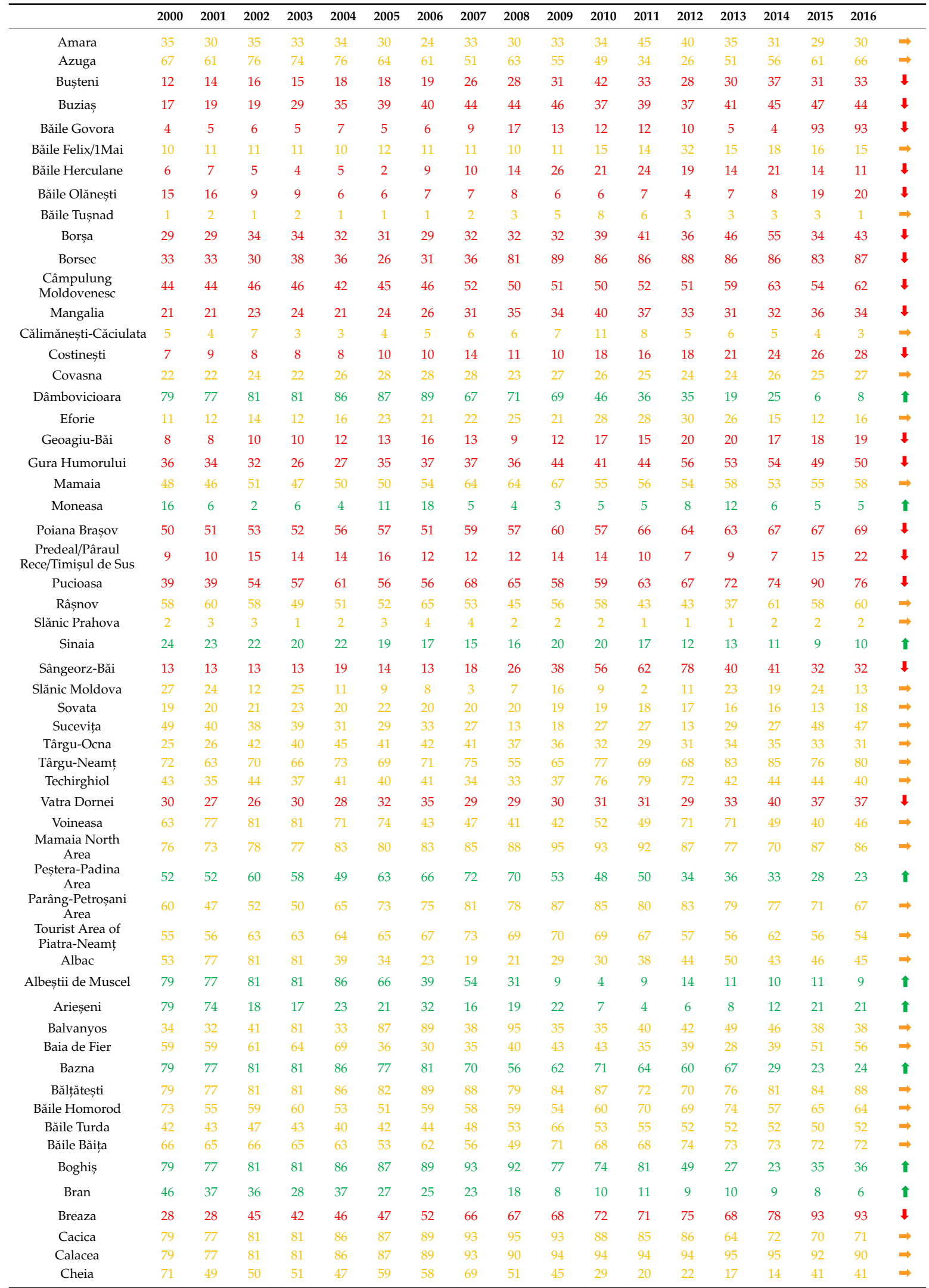


Table 3. Cont.

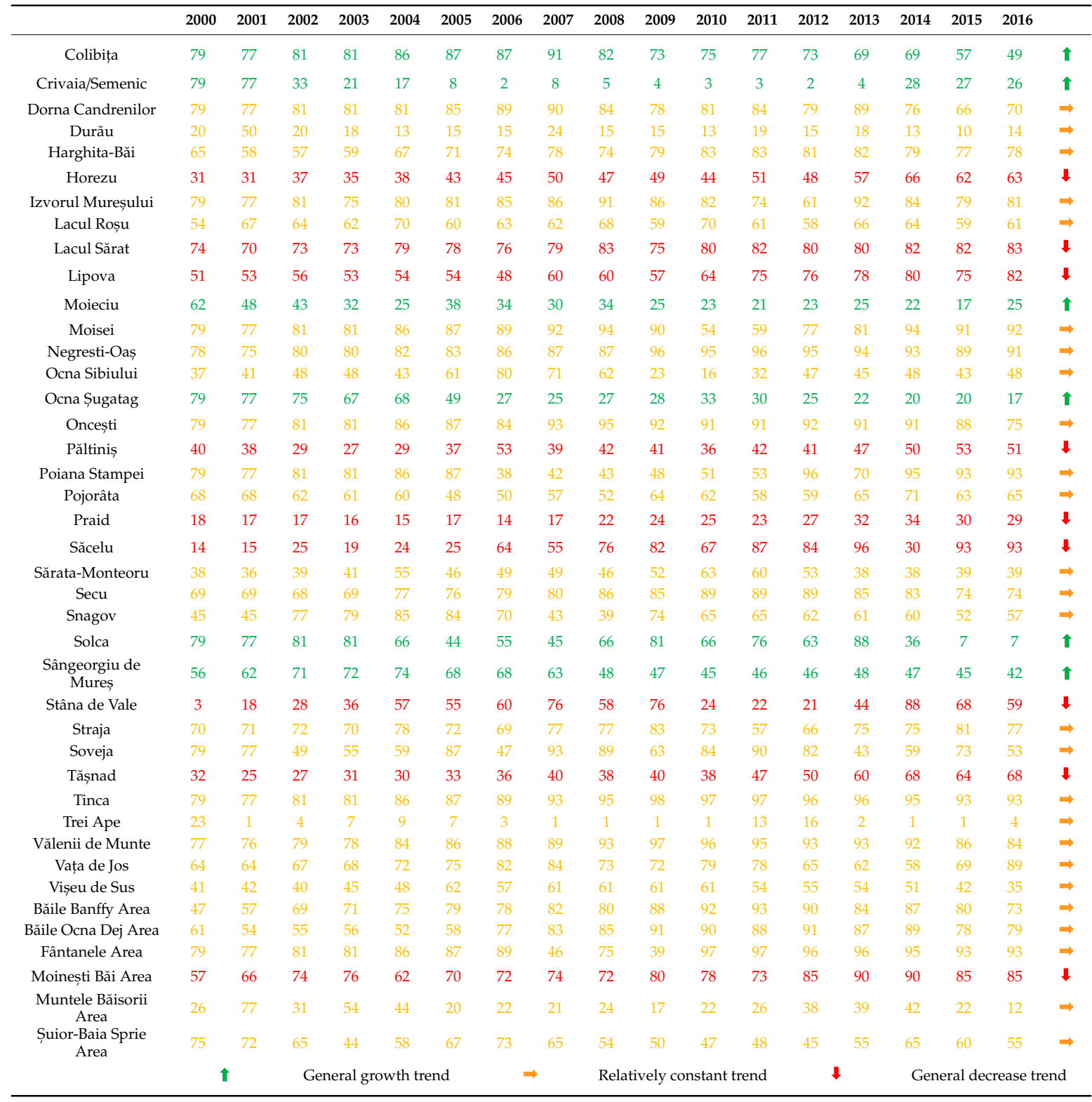

The next variation of the ranks analyzed is the share of the profit from tourism in the total profit of tourist resorts from Romania (Table 4). Most of the resorts, namely $43.9 \%$ of the total number of resorts have an evolution where tourism in their local economy is constant, is not the main sector, $36.7 \%$ show decreases in rank, being those resorts where the economic crisis has put most of its mark and only $19.4 \%$ of the total number of resorts have a growth trend. Examples of growth-trend resorts for the period 2000-2016: Dâmbovicioara, Moneasa, Slănic Prahova, Slănic Moldova (the resort that holds the first place in 2016 in terms of the profit in the tourism sector), Arieșeni, Bran (2nd place in 2016), Trei Ape (3rd place in 2016), Solca, etc. 
Table 4. Variation of the rankings for the share of profit from the tourism sector in the total profit.

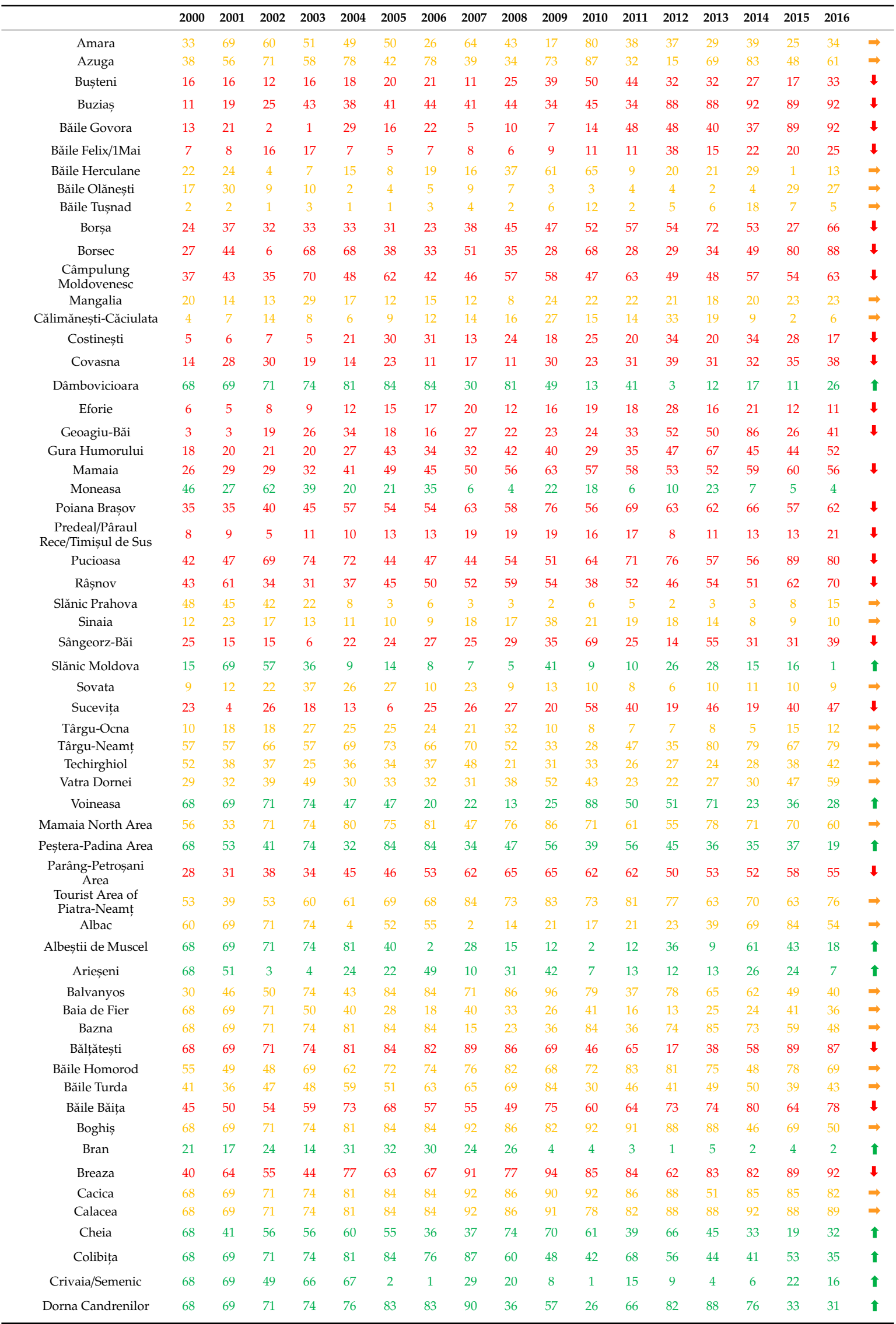


Table 4. Cont.

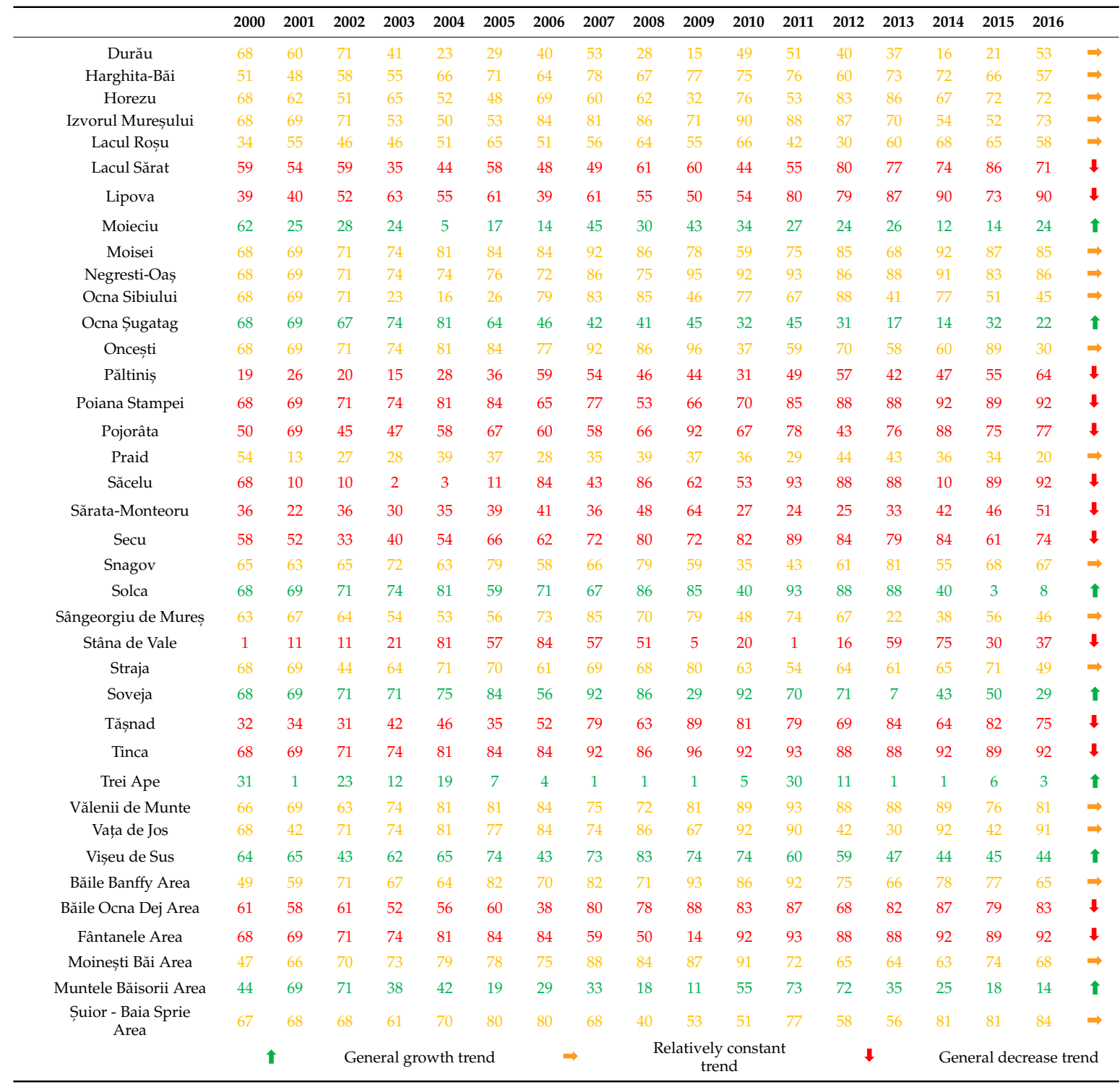

An analysis of the ranks on the arithmetic mean of the four economic indicators was done for each tourist resort from Romania (Table 5), which shows a predominance of the resorts that, over the course of 17 years, had a relatively constant trend, did not show large fluctuations, and which, out of the total number of resorts, account for 51\% (Băile Herculane, Borsec, Vatra Dornei, Slănic Prahova, Băile Turda, Trei Ape-this being the resort which holds the first place in the last 4 years, whose economic activity is mainly focused on tourism-in 2001, the total number of employees and the profit were $100 \%$ in the tourism sector).

With a smaller share of $28.6 \%$, are the resorts whose economic indicators have led to their decline over the whole period under review, this category being represented by resorts whose economic base is not tourist activity, but is supported by economic areas such as trade and industry (examples of resorts with drastic decreases in rank: Băile Govora, where all economic indicators in the tourism sector in the last two years of analysis had values equal to 0, Săcelu, Poiana Stampei, Tășnad, Stâna de Vale, Breaza). Last, is the category of resorts whose natural resources lay the foundations of their local economies where most of the revenue comes from tourism. Compared to the other two categories, it has the lowest number of resorts, the percentage being 19\% (Dâmbovicioara, which has shown a relatively constant trend in recent years in terms of tourism, Moneasa, Slănic Moldova, Arieșeni, Bran, Solca, Zona Muntele Băișorii, etc.) 
Table 5. Variation of the rankings for the arithmetic mean of the four economic indicators from the tourism sector.

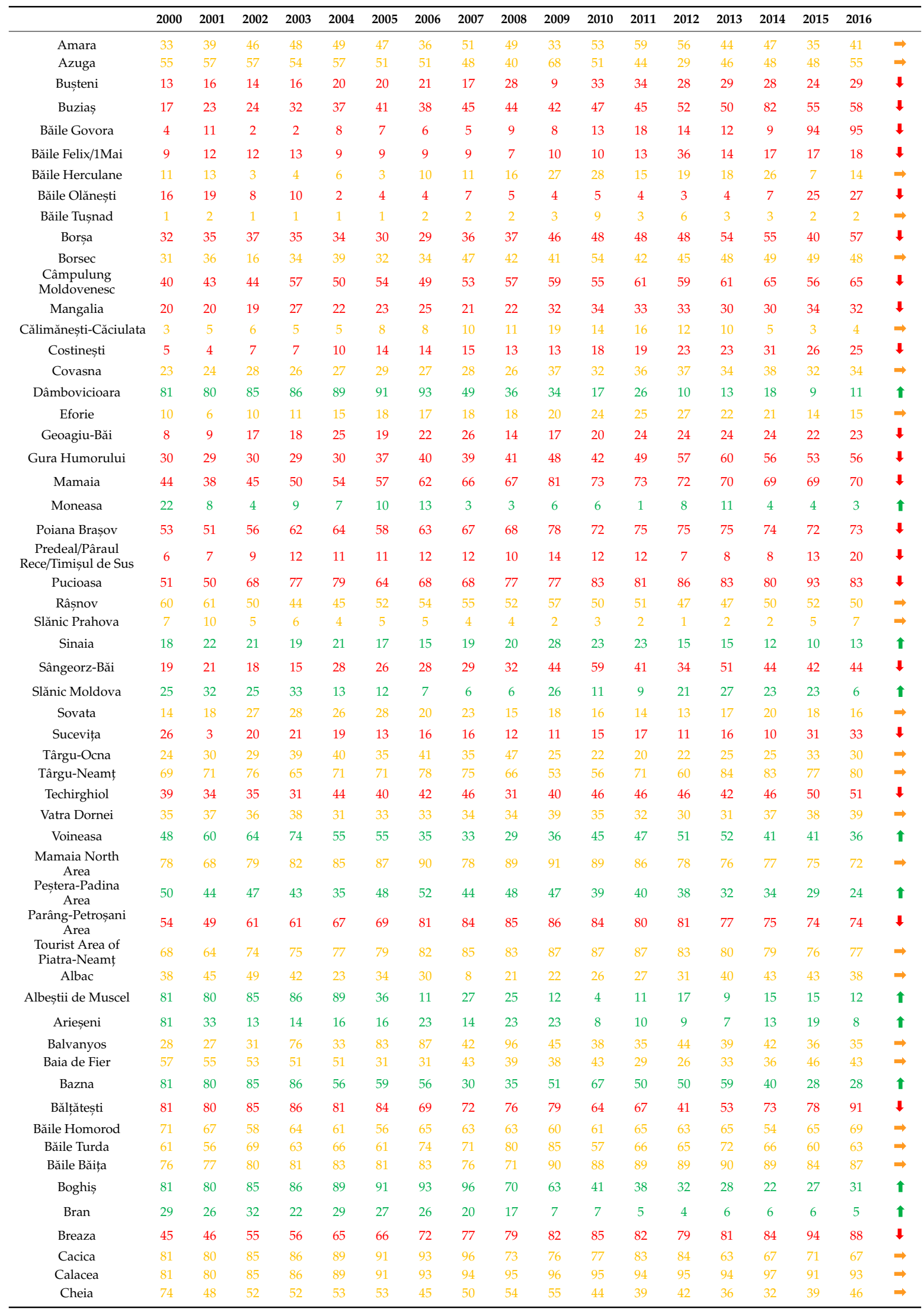


Table 5. Cont.

\begin{tabular}{|c|c|c|c|c|c|c|c|c|c|c|c|c|c|c|c|c|c|c|}
\hline & 2000 & 2001 & 2002 & 2003 & 2004 & 2005 & 2006 & 2007 & 2008 & 2009 & 2010 & 2011 & 2012 & 2013 & 2014 & 2015 & 2016 & \\
\hline Colibița & 81 & 80 & 85 & 86 & 89 & 91 & 86 & 92 & 82 & 67 & 70 & 77 & 62 & 55 & 58 & 63 & 47 & $\uparrow$ \\
\hline Crivaia/Semenic & 81 & 80 & 39 & 20 & 18 & 6 & 3 & 13 & 8 & 5 & 2 & 6 & 2 & 5 & 14 & 16 & 21 & $\boldsymbol{1}$ \\
\hline Durău & 15 & 25 & 26 & 17 & 14 & 15 & 19 & 22 & 19 & 15 & 19 & 22 & 20 & 26 & 16 & 12 & 22 & $\Rightarrow$ \\
\hline Harghita-Băi & 72 & 65 & 70 & 67 & 75 & 77 & 76 & 82 & 81 & 84 & 86 & 84 & 80 & 85 & 81 & 80 & 76 & $\Rightarrow$ \\
\hline Horezu & 36 & 42 & 48 & 46 & 52 & 50 & 59 & 59 & 60 & 49 & 65 & 58 & 68 & 68 & 72 & 70 & 68 & $\downarrow$ \\
\hline Lacul Roșu & 49 & 69 & 59 & 58 & 63 & 63 & 58 & 61 & 65 & 64 & 71 & 56 & 53 & 69 & 68 & 66 & 66 & $\Rightarrow$ \\
\hline Lacul Sărat & 73 & 72 & 77 & 66 & 72 & 80 & 80 & 79 & 86 & 83 & 82 & 85 & 88 & 88 & 85 & 87 & 82 & $\Rightarrow$ \\
\hline Lipova & 58 & 58 & 67 & 70 & 73 & 68 & 60 & 73 & 74 & 70 & 80 & 88 & 85 & 87 & 86 & 81 & 84 & $\downarrow$ \\
\hline Moieciu & 43 & 28 & 34 & 25 & 17 & 22 & 18 & 24 & 24 & 24 & 21 & 21 & 16 & 20 & 11 & 11 & 19 & $\boldsymbol{\uparrow}$ \\
\hline Moisei & 81 & 80 & 85 & 86 & 86 & 85 & 89 & 86 & 84 & 65 & 58 & 64 & 73 & 89 & 94 & 90 & 89 & $\Rightarrow$ \\
\hline Păltiniș & 34 & 41 & 33 & 30 & 41 & 46 & 71 & 57 & 53 & 56 & 49 & 55 & 58 & 56 & 61 & 64 & 71 & $\downarrow$ \\
\hline Poiana Stampei & 81 & 80 & 75 & 79 & 89 & 91 & 48 & 60 & 50 & 62 & 76 & 76 & 93 & 67 & 90 & 94 & 95 & $\downarrow$ \\
\hline Pojorâta & 52 & 52 & 40 & 41 & 48 & 44 & 39 & 37 & 38 & 43 & 36 & 43 & 43 & 41 & 45 & 44 & 45 & $\Rightarrow$ \\
\hline Praid & 21 & 15 & 22 & 23 & 24 & 25 & 24 & 25 & 30 & 31 & 29 & 28 & 35 & 35 & 35 & 30 & 26 & $\Rightarrow$ \\
\hline Săcelu & 27 & 17 & 23 & 8 & 12 & 21 & 46 & 40 & 58 & 72 & 69 & 78 & 77 & 78 & 27 & 94 & 95 & $\downarrow$ \\
\hline Sărata-Monteoru & 42 & 31 & 41 & 36 & 42 & 39 & 43 & 38 & 45 & 52 & 37 & 37 & 40 & 38 & 39 & 37 & 37 & $\Rightarrow$ \\
\hline Secu & 70 & 70 & 60 & 68 & 80 & 82 & 84 & 87 & 90 & 88 & 90 & 92 & 91 & 91 & 88 & 79 & 81 & $\Rightarrow$ \\
\hline Snagov & 47 & 53 & 71 & 72 & 74 & 76 & 67 & 62 & 61 & 66 & 60 & 57 & 74 & 73 & 71 & 59 & 60 & $\Rightarrow$ \\
\hline Solca & 64 & 80 & 64 & 49 & 62 & 49 & 47 & 54 & 75 & 80 & 66 & 69 & 76 & 79 & 33 & 8 & 9 & $\uparrow$ \\
\hline $\begin{array}{l}\text { Sângeorgiu de } \\
\text { Mures }\end{array}$ & 62 & 63 & 73 & 73 & 76 & 72 & 77 & 74 & 69 & 69 & 62 & 70 & 64 & 43 & 52 & 58 & 54 & $\Rightarrow$ \\
\hline Vața de Jos & 59 & 54 & 66 & 71 & 58 & 65 & 53 & 58 & 56 & 61 & 74 & 63 & 49 & 49 & 59 & 51 & 78 & $\Rightarrow$ \\
\hline Vișeu de Sus & 63 & 62 & 54 & 69 & 69 & 74 & 61 & 70 & 78 & 75 & 79 & 74 & 71 & 64 & 60 & 54 & 49 & $\boldsymbol{\uparrow}$ \\
\hline Băile Banffy Area & 66 & 75 & 81 & 80 & 82 & 86 & 85 & 90 & 87 & 92 & 91 & 91 & 87 & 86 & 87 & 82 & 79 & $\Rightarrow$ \\
\hline Băile Ocna Dej Area & 77 & 76 & 78 & 78 & 78 & 78 & 70 & 91 & 92 & 93 & 92 & 93 & 90 & 92 & 92 & 86 & 86 & $\Rightarrow$ \\
\hline Fântanele Area & 81 & 80 & 85 & 86 & 89 & 91 & 93 & 41 & 59 & 29 & 97 & 97 & 97 & 97 & 97 & 94 & 95 & $\Rightarrow$ \\
\hline Moinești Băi Area & 65 & 73 & 82 & 83 & 84 & 88 & 88 & 89 & 91 & 94 & 93 & 90 & 92 & 93 & 91 & 88 & 90 & $\Rightarrow$ \\
\hline $\begin{array}{c}\text { Muntele Băisorii } \\
\text { Area }\end{array}$ & 37 & 80 & 42 & 40 & 38 & 24 & 32 & 31 & 27 & 16 & 25 & 31 & 39 & 37 & 29 & 20 & 10 & $\uparrow$ \\
\hline $\begin{array}{c}\text { Suior - Baia Sprie } \\
\text { Area }\end{array}$ & 75 & 74 & 72 & 59 & 68 & 73 & 75 & 69 & 55 & 74 & 63 & 72 & 66 & 71 & 76 & 73 & 75 & $\Rightarrow$ \\
\hline & \multicolumn{2}{|c|}{$\boldsymbol{1}$} & \multicolumn{4}{|c|}{ General growth trend } & \multicolumn{2}{|c|}{$\Rightarrow$} & \multicolumn{4}{|c|}{ Relatively constant trend } & & \multicolumn{4}{|c|}{ General decrease trend } \\
\hline
\end{tabular}

Environmental conflicts can be defined by several characteristics, whose knowledge is essential for their management to reduce the negative impacts on society, the environment, and the economy [35]. The development of tourist resorts produces a series of negative effects on the environment. In Table 6, we analyzed the number of environmental conflicts that occurred in these tourist destinations in Romania, which are closely correlated with the development of tourism. Most conflicts occur in those resorts where tourism develops and represents its main economic sector (between 20 and 41 environmental conflicts: Moieciu resort, 41). At the opposite pole, with the fewest environmental conflicts, are the poorly developed tourist resorts (between zero and nine conflicts: Borșa, Buzias, Lipova, Păltiniș, 0). 
Table 6. The number of environmental conflicts in the tourist resorts from Romania.

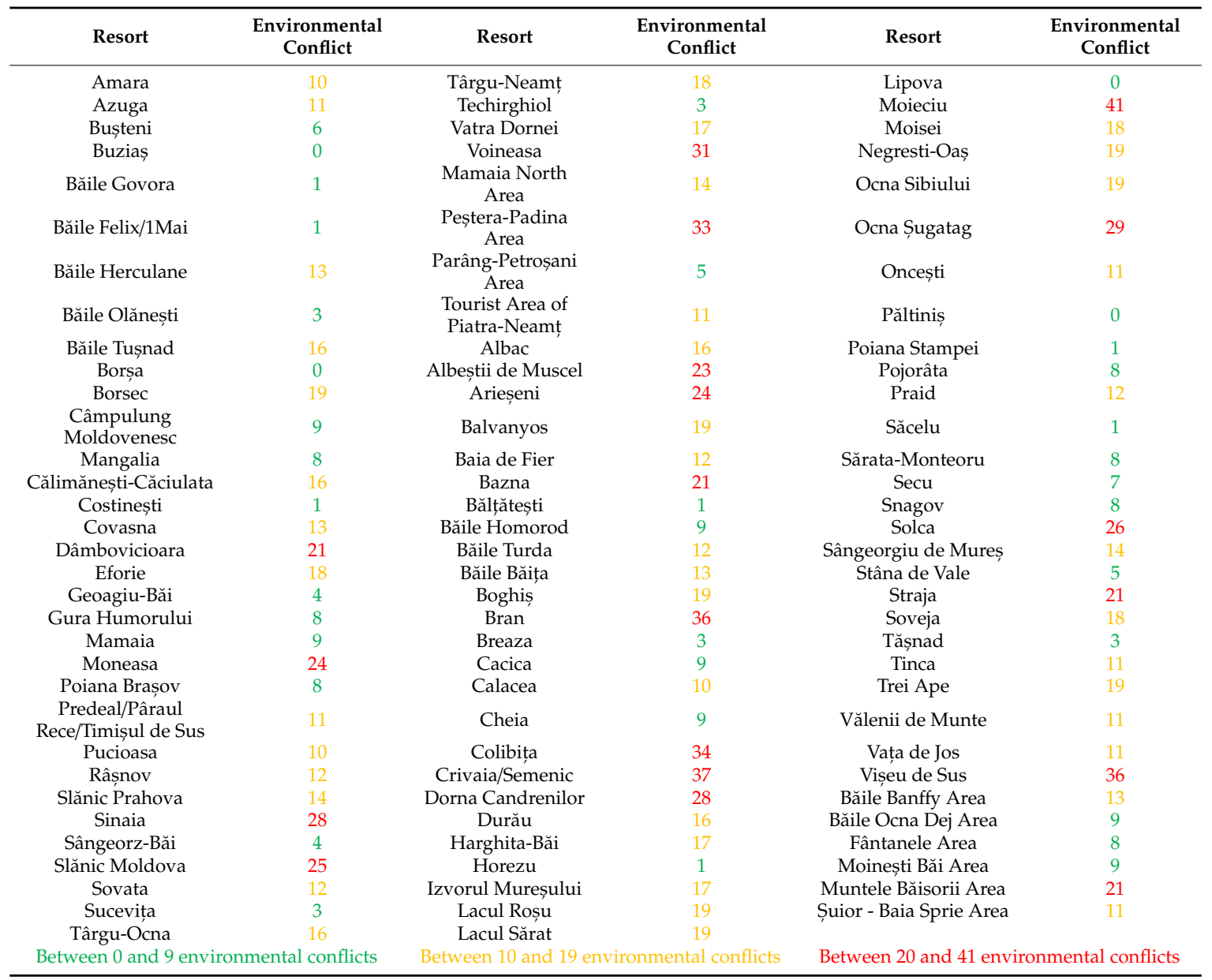

\section{Discussion and Conclusions}

The results obtained from the analyzes at the level of administrative-territorial unit, show the oscillating dynamics of the analyzed indicators and for the tourist resorts in Romania. A significant number of resorts in Romania have a paradoxical dynamic. Although, they are declared tourist resorts, the specific values of tourism have a low share, tourism being a complementary economic activity, whose dynamics are in a strong relationship with the general economic profile or almost do not interfere with the economic system, its contribution being reduced in their local economy, having other main fields of activity that support the revenues of these systems (Băile Herculane, retail). Thus, out of the total number of Romanian resorts, only $20 \%$ of them have as a predominant economic activity tourism, where the main income profile comes from the tourist activities (Trei Ape, Băile Tușnad, Costinești, Bran-resorts where the share of tourism in the main economic indicators is between $20 \%$ and $50 \%$ ). The obtained results confirm the relevance of the methodology used, because we obtained new elements regarding the specific dynamics of the local economies from the local economies with basic tourist function. The analyzes showed that the status of the tourist resort is not necessarily conditioned by the high share of tourist activities, but by a combination of factors, among them, the presence of tourist activities and the desire of the local authorities certified by the central authorities [36].

Detailed analyses of the relationship between tourism and the other economic activities of the local economy have highlighted a number of particular aspects in the resorts that have seen spectacular increases in the hierarchy. The most important aspect is the pressure on the environment to expand the accommodation spaces and, in particular, the leisure activities that require the availability of important land areas. This increasing pressure on the environment has been observed in numerous studies on 
deforestation in Romania [37,38], as well as in research on the impact of deforestation on the occurrence and development of imbalances in natural ecosystems [39-41]. Thus, it is necessary in future studies to carry out a detailed analysis of the deforestation areas for increasing the complexity of the tourist function in the tourist resorts in Romania.

The results obtained can contribute to the development of methodologies dedicated to the analysis of the role of tourism in the development of local economies, contributing to increasing the relevance of design models that measure the contribution of tourism to sustainable development at the local and regional level.

Author Contributions: Conceptualization, A.G., C.C.D., and R.C.D; methodology, A.G., A.K.G., and M.M.; software, C.O. and I.C.; validation, A.G. and C.T.; formal analysis, M.B. and M.G.; investigation, M.M.; resources, C.C.D. and M.M.; data curation, C.C.D.; writing-Original draft preparation, A.G., A.K.G., and M.M.; writing-Review and editing, A.G., M.M., C.C.D., and R.C.D.; visualization, A.G., C.O., M.G., and M.B.; supervision, M.M.; project administration C.C.D.; All authors have equal contribution to the preparation of this scientific paper.

Funding: This research received no external funding.

Conflicts of Interest: The authors declare no conflict of interest.

\section{References}

1. Kapera, I. Tourism in Poland following EU entry. Bull. Geogr. Socio-Econ. Ser. 2013, 22, 55-63. [CrossRef]

2. Eagles, P.F.J.; McCool, S.F.; Haynes, C.D. Sustainable Tourism in Protected Areas: Guidelines for Planning and Management; IUCN Gland: Gland, Switzerland; Cambridge, UK, 2002; p. 183.

3. Briedenhann, J.; Wickens, E. Tourism routes as a tool for the economic development of rural areas: Vibrant hope or impossible dream? Tour. Manag. 2004, 25, 71-79. [CrossRef]

4. Chen, C.F.; Chiou-Wei, S. Tourism expansion, tourism uncertainty and economic growth: New evidence from Taiwan and Korea. Tour. Manag. 2009, 30, 812-818. [CrossRef]

5. Croes, R.; Venegas, M. Cointegration and causality between tourism and poverty reduction. J. Travel Res. 2008, 47, 94-103. [CrossRef]

6. Holzner, M. Tourism and economic development: The beach disease? Tour. Manag. 2011, 32, 922-993. [CrossRef]

7. Ma, M.; Hassink, R. An evolutionary perspective on tourism area development. Ann. Tour. Res. 2013, 41, 89-109. [CrossRef]

8. Matarrita-Cascante, D. Changing communities, community satisfaction, and quality of life: A view of multiple perceived indicators. Soc. Indic. Res. 2010, 98, 105-127. [CrossRef]

9. Tang, C.; Tan, E. Does tourism effectively stimulate Malaysia's economic growth? Tour. Manag. 2015, 46, 158-163. [CrossRef]

10. Tugcu, C.T. Tourism and economic growth nexus revisited: A panel causality analysis for the case of the Mediterranean region. Tour. Manag. 2014, 42, 207-212. [CrossRef]

11. Garau-Vadell, J.B.; Gutierrez-Taño, D.; Diaz-Armas, R. Economic crisis and residents' perception of the impacts of tourism in mass tourism destinations. J. Destin. Mark. Manag. 2018, 7, 68-75. [CrossRef]

12. World Travel \& Tourism Council. Available online: https://www.wttc.org/ (accessed on 2 April 2019).

13. Buckley, R. Sustainable tourism: Research and reality. Ann. Tour. Res. 2012, 39, 528-546. [CrossRef]

14. Ruhanen, L.; Weiler, B.; Moyle, B.D.; McLennan, C.J. Trends and patterns in sustainable tourism research: A 25-year bibliometric analysis. J. Sustain. Tour. 2015, 23, 517-535. [CrossRef]

15. Molina-Azorín, J.F.; Font, X. Mixed methods in sustainable tourism research: an analysis of prevalence, designs and application in JOST (2005-2014). J. Sustain. Tour. 2016, 24, 549-573. [CrossRef]

16. Higgins-Desbiolles, F. Sustainable tourism: Sustaining tourism or something more? Tour. Manag. Perspect. 2018, 25, 157-160. [CrossRef]

17. Lee, T.H.; Jan, F.H. Can community-based tourism contribute to sustainable development? Evidence from residents' perceptions of the sustainability. Tour. Manag. 2019, 70, 368-380. [CrossRef]

18. Amado, R.; Picininik, M.; Jasmim, M. Sustainability and hotel business: criteria for holistic, integrated and participative development. J. Clean. Prod. 2017, 142, 217-224. 
19. Pulido-Fernández, J.I.; Andrades-Caldito, L.; Sánchez-Rivero, M. Is sustainable tourism an obstacle to the economic performance of the tourism industry? Evidence from an international empirical study. J. Sustain. Tour. 2015, 23, 47-64. [CrossRef]

20. Farsari, Y.; Butler, R.; Prastacos, P. Sustainable tourism policy for Mediterranean destinations: Issues and interrelationships. IJTP 2007, 1, 58-78. [CrossRef]

21. Hall, C.M. A typology of governance and its implications for tourism policy analysis. J. Sustain. Tour. 2011, 19, 437-457. [CrossRef]

22. Gkoumas, A. Evaluating a standard for sustainable tourism through the lenses of local industry. Heliyon 2019, 5, e02707. [CrossRef]

23. Council, Global Sustainable Tourism. Global Sustainable Tourism Criteria. 2013. Available online: https://www.gstcouncil.org/gstc-criteria/ (accessed on 25 June 2019).

24. Fernandez, J.I.P.; Rivero, M.S. Measuring tourism sustainability: proposal for a composite index. Tour. Econ. 2009, 15, 277-296. [CrossRef]

25. Schianetz, K.; Kavanagh, L. Sustainability indicators for tourism destinations: a complex adaptive systems approach using systemic indicator systems. J. Sustain. Tour. 2008, 16, 601-628. [CrossRef]

26. Rogerson, M.C.; Rogerson, J.M. Agritourism and local economic development in South Africa. Bull. Geogr. Socio-Econ. Ser. 2014, 26, 93-106. [CrossRef]

27. Faith, L.; Rogerson, C.M. Local economic development agencies and place-based development: Evidence from South Africa. Bull. Geogr. Socio-Econ. Ser. 2018, 41, $29-43$.

28. Hall, C.M.; Campos, M.J.Z. Public Administration and Tourism-International and Nordic Perspectives. Scand. J. Public Adm. 2014, 18, 3-17.

29. Ianoș, I.; Peptenatu, D.; Pintilii, R.D.; Drăghici, C.C. About sustainable development of the territorial emergent structures from the metropolitan area of Bucharest. Environ. Eng. Manag. J. 2012, 11, 1535-1545. [CrossRef]

30. Peptenatu, D.; Merciu, C.; Drăghici, C. Characteristics of entrepreneurial profile in some emergent territorial structures in Romania. Actual Probl. Econ. 2012, 12, 448-458.

31. Peptenatu, D.; Pintilii, R.; Drăghici, C.; Saghin, I.; Stoian, D.R. Management of Environment Risk within Emergency Territorial Systems. Case Study-the Influence Area of the Bucharest City. J. Environ. Prot. Ecol. 2012, 4, 2360-2370.

32. Rodríguez-Pose, A.; Palavicini-Corona, E.I. Does local economic development really work? Assessing LED across Mexican municipalities. Geoforum 2013, 44, 303-315. [CrossRef]

33. Christian, M.; Rogerson, C.M. Reframing place-based economic development in South Africa: The example of local economic development. Bull. Geogr. Socio-Econ. Ser. 2014, 24, $203-218$.

34. Mueller, H.; Kaufmann, E.L. Wellness tourism: Market analysis of a special health tourism segment and implications for the hotel industry. J. Vacat. Mark. 2001, 7, 15-17. [CrossRef]

35. Iojă, C.I.; Niță, M.R.; Vânău, G.O.; Onose, D.A.; Gavrilidis, A.A.; Hossu, C.A. Managementul Conflictelor de Mediu, 1st ed.; University Publishing House: Bucharest, Romania, 2015; p. 14.

36. Drăghici, C.C.; Pintilii, R.D.; Peptenatu, D.; Comănescu, L.G.; Sirodoev, I. The Role of SPA Tourism in the Development of Local Economies from Romania. In Proceedings of the 2nd Global Conference on Business, Economics, Management and Tourism, Prague, Czech Republic, 30-31 October 2014; pp. 1573-1577.

37. Pintilii, R.D.; Peptenatu, D.; Grecu, A.; Ilie, A.M.; Simion, A.G. Tourism, basic functionality versus complementary component of the territorial systems in Romania. In Proceedings of the International Conference-Environment at a Crossroads: SMART Approches for a Sustainable Future, Bucharest, Romania, 12-15 November 2015; pp. 364-372.

38. Drăghici, C.C.; Andronache, I.; Ahammer, H.; Peptenatu, D.; Pintilii, R.D.; Ciobotaru, A.M.; Simion, A.G.; Dobrea, R.C.; Diaconu, D.C.; Vișan, M.C. Spatial evolution of forest areas in the northern Carpathian Mountains of Romania. Acta Montan. Slovaca 2017, 22, 95-106.

39. Diaconu, D.C.; Andronache, I.; Pintilii, R.D.; Breţcan, P.; Simion, A.G.; Drăghici, C.C.; Gruia, A.K.; Grecu, A.; Marin, M.; Peptenatu, D. Using fractal fragmentation and compaction index in analysis of the deforestation process in Bucegi Mountains Group, Romania. Carpathian J. Earth Environ. 2019, 14, 431-438. 
40. Pintilii, R.D.; Andronache, I.; Diaconu, D.C.; Dobrea, R.C.; Zelenakova, M.; Fensholt, R.; Peptenatu, D.; Drăghici, C.C.; Ciobotaru, A.M. Using Fractal Analysis in Modeling the Dynamics of Forest Areas and Economic Impact Assessment: Maramures County, Romania as a Case Study. Forests 2017, 8, 25. [CrossRef]

41. Andronache, I.; Fensholt, R.; Ahammer, H.; Ciobotaru, A.M.; Pintilii, R.D.; Peptenatu, D.; Drăghici, C.C.; Diaconu, D.C.; Radulovic, M.; Pulighe, G.; et al. Assessment of Textural Differentiations in Forest Resources in Romania Using Fractal Analysis. Forests 2017, 8, 54. [CrossRef]

(C) 2019 by the authors. Licensee MDPI, Basel, Switzerland. This article is an open access article distributed under the terms and conditions of the Creative Commons Attribution (CC BY) license (http://creativecommons.org/licenses/by/4.0/). 